\title{
APLIKASI METODE SUKACITA (SUSUN ANGKA CIPTAKAN CERITA) DALAM PEMBELAJARAN TEMATIK KELAS 1
}

\author{
Septiana Agustin \\ Doctoral Program of Sebelas Maret University, Jl. Ir. Sutami 36A, Surakarta, Indonesia \\ septiana.agustin@gmail.com
}

\begin{abstract}
This study aims to apply innovative learning methods. New methods that are expected to provide references for teachers, especially low-class teachers. The method used in this study is a qualitative descriptive method. Data collection techniques are based on observations that cover several aspects. Observations are carried out in stages by comparing classes that apply the new method and those that do not. The data analysis technique is done by qualifying the observational data. The research results are shown based on observations by the teacher during the learning activities. There are differences when learning with the same material, but delivered by different methods. That is because the new method has several advantages, among others: children are more enthusiastic to play together, familiarize children with tolerance by not picking friends, class conditions more orderly, creating a pleasant atmosphere, and training children to work while learning in group dynamics.

Keyword: method, innovative, creative, simultaneous, two sides.
\end{abstract}

\section{Pendahuluan}

Sistem pendidikan di Indonesia saat ini sedang mengarah kepada pengembangan kreativitas anak melalui para fasilitator yaitu tenaga pendidik yang tertuang dalam pembaharuan Kurikulum 2013. Sebuah inovasi dalam hal perencanaan dan penyelenggaraan sistem pendidikan untuk menggali dan memaksimalkan potensi para peserta didik. Secara mendasar, tema Kurikulum 2013 adalah menghasilkan insan Indonesia yang: produktif, kreatif, inovatif, afektif; melalui penguatan sikap, keterampilan, dan pengetahuan yang terintegrasi (Mulyasa, 2013). Untuk mewujudkan hal tersebut, diperlukan tenaga pendidik profesional yang terus berupaya untuk merancang dan mengorganisasikan pembelajaran secara aktif, efektif, menyenangkan serta bermakna.

Merencanakan dan melaksanakan kegiatan pembelajaran berkualitas membutuhkan persiapan yang matang. Memberikan materi pengajaran bukanlah sesuatu yang dapat dikerjakan dengan asal-asalan. Dalam hal ini, guru mengemban tugas yang tidak sedikit. Selain menyiapkan materi pelajaran, guru juga harus membuat metode dan alat pergaa yang dapat mendukung kegiatan pembelajaran. Dalam mendidik anak, tidak cukup bagi seorang guru hanya dengan menguasai materi pembelajaran, tapi juga harus menguasai metode penyampaiannya (Sutikno, 2014). 
Syafaruddin dan Nasution (2005) mengemukakan bahwa proses suatu sistem dimulai dari input (masukan) kemudian diproses dengan berbagai aktivitas dengan menggunakan teknik dan prosedur dan selanjutnya menghasilkan output (keluaran), yang akan dipakai oleh masyarakat lingkungannya. Metode pembelajaran yang variatif, kreatif dan inovatif (proses) sangat penting untuk menghasilkan lulusan (output) yang berkompetensi. Guru diharapkan mampu membuat atau mengembangkan metode serta media pembelajaran yang menarik dan tepat guna bagi para peserta didik. Dengan menyelenggarakan kegiatan pembelajaran yang berkualitas dan menyenangkan, maka akan berdampak pada meningkatnya potensi dan prestasi peserta didik yang akan menghasilkan keluaran berupa lulusan cerdas dan berkualitas.

Undang-undang Republik Indonesia Nomor 20 tahun 2003 tentang Sistem Pendidikan Nasional pada penjelasan Pasal 35, memaparkan bahwa "Kompetensi lulusan merupakan kualifikasi kemampuan lulusan yang mencakup sikap, pengetahuan dan keterampilan sesuai dengan standar nasional yang sudah disepakati." Maka pendidikan sebagai sebuah sistem adalah pendidikan sebagai suatu keseluruhan, baik teori mengenai sistem hingga sistem pendidikan nasional dan sekolah (Suparlan, 2008). Dalam hal ini, capaian kompetensi lulusan yang diharapkan tidak hanya mencuat dalam hal akademik, akan tetapi memiliki integritas tinggi dalam hal kepribadian dan sosial. Berhasil tidaknya para peserta didik bukan semata-mata menjadi tanggungjawab guru di sekolah. Namun, membutuhkan keterlibatan dari beberapa pihak, antara lain: keluarga, sekolah, pemerintah, dan masyarakat.

Salah satu capaian sistem pendidikan nasional adalah mencetak generasi penerus bangsa yang cerdas dan berkualitas. Hal terpenting dalam program peningkatan kualitas tersebut adalah niat dan kemauan guru untuk kreatif dan bertanggung jawab terhadap keberhasilan pekerjaannya (Chatib, 2011). Tidak hanya sekadar memenuhi jam mengajar, akan tetapi mengupayakan yang terbaik bagi perkembangan anak di sekolah. Untuk memfasilitasi peserta didik dengan pelayanan yang prima, maka para tenaga pengajar memerlukan kemauan ekstra untuk merancangkan pembelajaran secara kreatif dan inovatif. Ada beragam metode yang dapat digunakan oleh guru dalam kegiatan pembelajaran. Oleh karena itu, penelitian ini memaparkan sebuah metode yang dapat digunakan sebagai referensi mengajar bagi guru khususnya di kelas rendah. Metode ini dibuat dengan bahan sederhana, agar dapat dengan mudah dipahami oleh para pendidik.

Metode ini menginovasi metode yang sudah ada, namun disajikan dalam bentuk dan aplikasi yang berbeda. Metode sederhana yang dapat dengan mudah dipraktikkan oleh guru 
dalam kegiatan pembelajaran, yaitu metode "sukacita" (susun angka ciptakan cerita). Penggunaan metode "sukacita" ini memanfaatkan media two side untuk mendukung kegiatan pembelajaran. Metode ini diaplikasikan pada pembelajaran tematik kelas 1 semester gasal di SD Negeri Sudirman Kecamatan Ambarawa Kabupaten Semarang. Oleh karena itu, metode "sukacita" ini dapat digunakan untuk berbagai mata pelajaran, antara lain: Matematika, Bahasa Indonesia, Pendidikan Kewarganegaraan, dan Seni Budaya. Pada mata pelajaran Bahasa Indonesia juga meliputi bahasan yang menyangkut topik alam maupun sosial.

Beragam metode pembelajaran yang kreatif, inspiratif dan menyenangkan dapat dipraktikkan oleh guru sebagai upaya mewujudkan kegiatan pembelajaran yang menarik bagi anak didik. Upaya menciptakan suasana pembelajaran yang menarik dan menyenangkan harus disesuaikan dengan karakter anak didik. Oleh karena itu, maka perlu memilih strategi yang tepat. Strategi pembelajaran mencakup metode, model, dan alat peraga. Metode atau model pembelajaran yang dipilih, diharapkan dapat memotivasi peserta didik dalam kegiatan pembelajaran. Rancangan inovasi pembelajaran pada karya inovasi ini tergolong sederhana, namun berdampak besar bagi kegiatan pembelajaran tematik, khususnya di kelas rendah. Rancangan inovasi yang diterapkan dalam karya inovasi ini adalah tentang penggunaan metode "sukacita” yang diaplikasikan pada pembelajaran tematik kelas 1 semester gasal di SD Negeri Sudirman. Aplikasi metode "sukacita" nantinya akan dipadukan dengan model two side, sehingga menjadi sebuah temuan baru. Penggunaan metode ini dapat diterapkan di kelas rendah pada jenjang sekolah dasar.

\section{Metode}

Metode yang digunakan dalam penelitian ini adalah metode deskriptif kualitatif. Metode yang secara lengkap menjelaskan langkah-langkah penggunaan metode dengan media two side sebagai pendukung. Teknik pengumpulan data berdasarkan hasil observasi dan wawancara yang mencakup beberapa aspek, antar alain: aspek suasana kelas, kondisi kelas, model belajar, waktu, dan tingkat kejenuhan siswa. Observasi dilakukan secara bertahap dengan membandingkan antara kelas yang menerapkan metode "sukacita" dan yang tidak. Teknik analisis data dilakukan dengan cara mengualitatifkan data hasil observasi. Wawancara dilakukan kepada guru kelas sebanyak dua kali, yaitu pada saat menerapkan metode "sukacita" dan metode hafalan.

\section{Hasil dan Pembahasan}


Sesuai dengan kepanjangan dari "sukacita", maka hasil metode ini adalah mengajarkan kepada anak untuk menyusun angka dan sekaligus menciptakan cerita. Proses pembuatan metode "sukacita" menggunakan media two side. Langkah awal dalam menerapkan metode "sukacita" ini adalah membuat media two side terlebih dahulu. Media two side dibuat dengan cara menentukan gambar dan jumlah angka. Setelah itu, dibuat menjadi dua sisi yang berukuran dan berpotongan sama panjang. Sisi yang satu adalah urutan angka dari 1 - 20 atau $1-25$, sedangkan sisi yang lain adalah gambar. Gambar yang dicetak adalah binatang, tumbuhan, dan lingkungan sekitar. Kedua sisi tersebut dicetak pada kertas BC (kertas ukuran HVS agak tebal). Setelah tercetak, dipotong satu per satu sesuai garis kotak yang ada. Potongan-potongan gambar dimasukkan ke dalam sebuah tempat agar tidak tercecer. Untuk lebih jelasnya, dapat disimak pada sintak metode "sukacita". Persiapan metode "sukacita" dapat dilakukan dengan mengacu sintak berikut ini.

1. Menentukan gambar yang akan dipakai sebagai bahan cerita untuk anak. Gambar disesuaikan dengan tema yang dipakai dalam pembelajaran tematik. Sebaiknya, gambar yang dipilih mengandung unsur menarik bagi anak.

2. Menentukan urutan bilangan yang akan diajarkan kepada anak. Urutan bilangan tersebut bisa 1 s.d. 20, 1 s.d. 25, atau 1 s.d. 50 . Urutan bilangan tersebut dibuat dalam bentuk tabel dan diurutkan dari kiri atas ke kanan.

3. Menyusun gambar dan urutan bilangan dalam dua halaman. Sesuaikan ukuran gambar dan tabel bilangan agar keduanya sama. Sehingga, akan memudahkan saat dicetak.

4. Menyiapkan kertas BC atau kertas ukuran HVS F4 yang tebal untuk mencetak media two side.

5. Mencetak gambar dan urutan bilangan secara bergantian (bolak balik). Hasil cetak atau print berupa sebuah kertas dengan dua sisi yang berbeda. Satu sisi berupa gambar, sedangkan sisi yang lain adalah urutan bilangan.

6. Menggunting urutan bilangan sesuai garis-garis pada tabel, sehingga hasil potongan rapi. (satu kotak satu bilangan).

7. Menyiapkan kantong atau amplop sebagai wadah untuk menaruh potongan-potongan bilangan. Ukuran potongan kertas disesuaikan dengan ukuran plastik pres/ stopmap plastik yang digunakan. Bisa menggunakan separuh atau setengah ukuran stopmap, atau menggunakannya secara penuh.

Penerapan metode "sukacita" dapat dilakukan dengan mengacu sintak berikut ini.

1. Mengeluarkan potongan-potongan kertas yang ada di dalam kantong atau amplop. 
2. Memposisikan semua potongan kertas terbuka pada angka atau menunjukkan bilangan.

3. Membuka plastik pres atau stopmap plastik untuk memasukkan potongan-potongan kertas satu per satu.

4. Mengurutkan bilangan mulai dari yang terkecil hingga terbesar.

5. Meletakkan bilangan pertama pada ujung kiri bagian atas.

6. Mencari urutan bilangan selanjutnya untuk diurutkan satu baris ke kanan hingga tidak ada lagi ruang kosong.

7. Melanjutkan urutan bilangan secara teratur dimulai kembali dari ujung kiri sampai ujung kanan. Dilakukan dengan pola yang sama hingga semua bilangan tertata secara urut.

8. Menutup plastik pres atau stopmap plastik agar potongan-potongan kertas yang sudah tersusun tidak tercecer atau berantakan.

9. Melihat gambar yang terbentuk dengan urutan bilangan yang sudah jadi. Jika urutan bilangan ditata secara benar, maka gambar yang terbentuk juga benar.

10. Menceritakan gambar yang terbentuk dengan menggunakan kalimat sendiri.

Pengaplikasian metode "sukacita" meliputi dua cara, yaitu: susun angka dan ciptakan cerita. Angka-angka yang tersebar disusun dari angka yang paling kecil yaitu 1. Angka 1 diletakkan di atas pada ujung sebelah kiri, kemudian dilanjutkan dengan menempatkan angka yang lain sesuai urutan. Setelah angka tersusun rapi, maka gambar bisa dibalik untuk melihat sisi yang lain. Pada sisi lainnya, nampak sebuah gambar yang terbentuk. Kemudian, anak-anak mulai menyebutkan, mengamati, mendeskripsikan, lalu memaparkan tentang gambar tersebut. Pembuatan deskripsi gambar dituliskan oleh anak di buku tulis masing-masing, kemudian dipresentasikan satu per satu di muka kelas.

Hasil penelitian ditujukkan berdasarkan pengamatan yang dilakukan oleh guru selama kegiatan pembelajaran berlangsung. Pengamatan dilakukan pada waktu dan tempat yang berbeda. Berdasarkan hasil observasi, ada perbedaan antara siswa yang diajarkan berhitung menggunakan metode hafalan dan metode "sukacita". Pembelajaran menggunakan materi yang sama, namun disampaikan dengan metode yang berbeda. Hasil yang didapatkan juga berbeda. Hal itu dikarenakan metode "sukacita" memiliki beberapa kelebihan, antara lain: anak-anak lebih antusias untuk bermain bersama-sama di dalam kelompok, membiasakan anak untuk toleransi dengan cara tidak memilih-milih teman, kondisi kelas lebih tertib, tercipta suasana menyenangkan, serta melatih anak untuk bekerja sekaligus belajar dalam dinamika kelompok. 
Adapun crtitical accident yang terjadi pada saat pembelajaran berlangsung dengan metode "sukacita".

1. "Wah, asyik ya menyusun angka dan gambar ini."

2. “Aku penasaran sekali, nanti jadinya gambar apa ya?”

3. "Eh, tempatnya bukan disitu tapi di sebelah sini, lho."

4. "Hei, aku bisa menebak itu gambar apa meski angka yang kita susun belum selesai."

5. "Hore, kelompok kita selesai yang pertama!"

6. "Bu, kelompok kami sudah selesai."

7. "Yes, aku sudah hafal!"

8. "Aku mau cerita tentang masa kecilku, ah."

Beberapa crtitical accident secara spontan muncul di dalam kelas saat kegiatan pembelajaran berlangsung. Hal itu juga terjadi di kelas yang tidak menerapkan metode "sukacita". Berikut contoh crtitical accident yang terjadi di dalam kegiatan pembelajaran yang menerapkan metode menghafal.

Hasil pengamatan dalam hal berhitung menggunakan metode menghafal berpengaruh terhadap kondisi siswa di dalam kelas. Suasana kelas terlihat membosankan, kondisi siswa gaduh dan berisik, serta kurangnya daya konsentrasi anak dalam mengikuti kegiatan pembelajaran. Selain itu, kejenuhan anak terlihat saat beberapa anak meminta ijin meninggalkan ruang kelas dengan berbagai alasan. Ada 1 anak ijin buang air kecil, lalu 2 orang temannya menyusul. Ada 1 anak ijin membeli alat tulis di koperasi dengan mengajak 1 orang teman untuk menemani. Ada 2 anak ijin meraut pensil di luar kelas, dan ada 1 anak ijin untuk cuci tangan. Model pembelajaran yang diterapkan bersifat individu. Siswa menghafalkan urutan bilangan sendiri-sendiri di bawah bimbingan dan pengawasan guru.

Hasil analisis taraf serap menggunakan metode hafalan (berupa prosentase), antara lain: pemahaman siswa sebesar 75\%, hafalan sebesar 70\%, dan pencapaian tujuan sebesar $70 \%$. Mata pelajaran yang diterapkan adalah khusus menghafalkan urutan bilangan. Disampaikan oleh guru kelas bahwa waktu yang diperlukan oleh semua siswa dapat menghafal urutan bilangan adalah 1 sampai dengan 2 bulan. Hal itu ditentukan oleh gaya belajar siswa dan tingkat kecerdasan siswa yang beragam. Ada siswa yang bisa menghafalkan dalam keadaan tenang, ada pula yang menghafalkan dengan cara mendengarkan teman yang sedang menghafalkan. Ada siswa yang menghafalkan dengan cara menyebutnya dalam hati, namun ada siswa yang akan hafal ketika menyuarakan apa yang dihafalkannya. Ada siswa yang hafal hanya dengan 
mendengarkan, namun ada siswa yang lebih mudah menghafal dengan cara menulis atau mencatatnya dalam bentuk tulisan.

Hasil pengamatan dalam hal berhitung menggunakan metode "sukacita" berpengaruh terhadap kondisi siswa di dalam kelas. Suasana kelas terlihat menyenangkan dan penuh antusias. Kondisi siswa di dalam kelas tampak tertib saat guru membagi mereka ke dalam beberapa kelompok. Satu per satu bergabung di dalam kelompok mereka masing-masing. Para siswa belajar dan bekerja sama di dalam kelompok. Ada yang terlihat bingung untuk menyusun urutan bilangan, lalu membalik plastik pres atau stopmap plastik untuk memastikan gambar yang terbentuk. Ada kelompok yang sangat cepat bekerja sama, sehingga dapat selesai lebih dahulu. Selama pembelajaran berlangsung, tidak ada siswa yang ijin untuk melakukan aktivitas yang lain.

Hasil analisis taraf serap menggunakan metode "sukacita" (berupa prosentase), antara lain: pemahaman siswa sebesar 80\%, hafalan sebesar 90\%, dan pencapaian tujuan sebesar $95 \%$. Mata pelajaran yang diterapkan tidak hanya matematika tentang mengurutkan bilangan, akan tetapi juga mencakup beberapa materi pelajaran yang lain seperti Bahasa Indonesia, Pendidikan Kewarganegaraan, dan Seni Budaya. Pada mata pelajaran Bahasa Indonesia, dapat dikembangkan secara luas pada bahasan atau bidang Ilmu Pengetahuan Alam maupun Sosial. Salah satu contohnya, gambar yang terbentuk dari urutan bilangan adalah kelinci. Guru dapat mengambil topik tentang kelinci untuk dimasukkan ke dalam mata pelajaran yang lain. Khusus dalam penelitian ini adalah melatih siswa untuk cakap berbicara melalui cerita yang mereka ciptakan. Siswa dapat menceritakan tentang ciri-ciri kelinci, tempat hidup kelinci, cara kelinci mendapatkan makanan, dan juga tentang kesukaan menjadikan kelinci sebagai hewan piaraan. Penyampaian materi pelajaran yang saling terkait dan terhubung namun tetap dalam satu kesatuan yang padu disebut sebagai pembelajaran berbasis Tematik.

Kemampuan siswa yang dilatih dan dikembangkan tidak hanya mengurutkan bilangan, akan tetapi juga mengembangkan daya imajinasi siswa, daya konsentrasi siswa, kreativitas siswa, serta kecakapan siswa dalam mengutarakan ide atau gagasan mereka melalui cerita yang dipaparkan. Keragaman aktivitas dan kemampuan siswa yang dilatih dalam satu waktu inilah yang menjadi keunggulan metode "sukacita". Peneliti menamakannya dengan istilah metode simultan. Sebuah metode yang tidak monoton dan memberikan banyak fasilitas untuk siswa menggali dan mempertajam kemampuan dan kecerdasan mereka.

Hasil wawancara dengan guru kelas, disampaikan bahwa waktu yang diperlukan oleh semua siswa dapat menghafal urutan bilangan adalah $3-4$ minggu. Hal itu dirangsang oleh 
metode yang digunakan oleh guru, yaitu metode "sukacita". Sebuah metode inovasi yang dilakukan secara bertahap dan berkesinambungan di dalam kegiatan pembelajaran. Tidak hanya siswa yang diuntungkan, melainkan juga guru khususnya dalam hal memberikan penilaian untuk beberapa kategori kemampuan siswa dalam satu waktu.

Tabel 1. Hasil Pengamatan Berhitung Menggunakan Metode Menghafal

\begin{tabular}{|c|c|c|c|c|}
\hline Suasana Kelas & Kondisi Siswa & Model Belajar & Waktu & Siswa Ijin \\
\hline Bosan & Gaduh & Individu & $1-2$ bulan & 8 anak \\
\hline
\end{tabular}

Tabel 2. Hasil Pengamatan Berhitung Menggunakan Metode SUKACITA

\begin{tabular}{|c|c|c|c|c|}
\hline Suasana Kelas & Kondisi Siswa & Model Belajar & Waktu & Siswa Ijin \\
\hline Menyenangkan & Tertib & Kerja sama & $3-4$ minggu & Tidak ada \\
\hline
\end{tabular}

Tabel 3. Hasil Analisis Taraf Serap Menggunakan Metode Hafalan

\begin{tabular}{|c|c|c|c|c|}
\hline Pemahaman & Hafalan & Mata Pelajaran & $\begin{array}{c}\text { Model } \\
\text { Pembelajaran }\end{array}$ & $\begin{array}{c}\text { Pencapaian } \\
\text { Tujuan }\end{array}$ \\
\hline $75 \%$ & $70 \%$ & 1 & Terpisah & $70 \%$ \\
\hline
\end{tabular}

Tabel 4. Hasil Analisis Taraf Serap Menggunakan Metode SUKACITA

\begin{tabular}{|c|c|c|c|c|}
\hline Pemahaman & Hafalan & Mata Pelajaran & $\begin{array}{c}\text { Model } \\
\text { Pembelajaran }\end{array}$ & $\begin{array}{c}\text { Pencapaian } \\
\text { Tujuan }\end{array}$ \\
\hline $80 \%$ & $90 \%$ & Beragam & Holistik & $95 \%$ \\
\hline
\end{tabular}

\section{Kesimpulan}

Tugas utama guru adalah merencanakan dan menyelenggarakan pembelajaran yang prima bagi pesera didik. Untuk menciptakan pembelajaran yang efektif, menarik, dan menyenangkan, guru harus memiliki strategi dalam menyampaikan materi ajarnya. Salah satu strategi yang dapat dilakukan oleh guru adalah memanfaatkan media, metode, dan alat peraga dalam pembelajaran. Dengan menggunakan beragam media dan atau alat peraga serta beraneka metode dalam pembelajaran, maka kegiatan pembelajaran tidak akan terasa menjenuhkan. Peserta didik akan merasa lebih antusias, bersemangat, dan terdorong kreativitas mereka. Dengan demikian, efektivitas dan optimalisasi belajar mengajar dapat tercapai dengan indikator memuaskan. 
Salah satu metode yang dikembangkan dalam penelitian ini adalah penggunaan metode "sukacita" yang dipadukan dengan model two side dalam kegiatan pembelajaran. Metode "sukacita" dapat digunakan khususnya jenjang sekolah dasar kelas rendah. Metode "sukacita" juga merupakan salah satu metode simultan yang dapat digunakan untuk berbagai mata pelajaran, antara lain: Matematika, Bahasa Indonesia, Pendidikan Kewarganegaraan, dan Ilmu Pengetahuan Alam maupun Sosial. Pada mata pelajaran Bahasa Indonesia juga meliputi bahasan yang menyangkut topik alam maupun sosial. Dengan demikian, pembelajaran dengan metode "sukacita" berpadu dengan model two side merupakan salah satu metode inovatif yang dapat mendukung kreativitas peserta didik.

Keunggulan metode "sukacita" adalah dapat digolongkan sebagai metode yang holistik. Sebuah metode yang berisi gabungan dari beberapa materi pelajaran, namun disampaikan atau diajarkan dalam suatu kegiatan pembelajaran yang terpadu. Metode "sukacita" yang dipadukan dengan model two side berbasis pada pembelajaran tematik. Mencakup unsur mata pelajaran yang beragam, namun tetap dalam satu bingkai topik yang sama. Keunggulan metode "sukacita" adalah sebagai metode simultan. Sebuah inovasi pembelajaran yang melatih dan mengembangkan kemampuan siswa dalam beberapa aspek, antara lain: mengurutkan bilangan, meningkatkan daya imajinasi, melatih daya konsentrasi, menajamkan kreativitas siswa, serta melatih kecakapan siswa dalam mengutarakan ide atau gagasan mereka melalui cerita yang dipaparkan. Keragaman aktivitas dan kemampuan siswa yang dilatih dalam satu waktu inilah yang menjadi keunggulan metode "sukacita".

\section{Acknowledgement}

Penelitian ini mendapatkan bantuan moril dari beberapa pihak, antara lain: kepala sekolah, guru, dan siswa sekolah dasar negeri Sudirman. Selanjutnya terkait pembiayaan dalam penelitian ini dilakukan secara mandiri oleh peneliti.

\section{Referensi}

Chatib, Munif. (2011). Gurunya Manusia. Cetakan 1, Bandung : Kaifa Learning. Kartono, ST. (2011). Menjadi Guru untuk Muridku. Yogyakarta : Kanisius (Anggota IKAPI).

Mulyasa. (2013). Pengembangan Implementasi Kurikulum 2013. Cetakan Pertama. Bandung : PT Remaja Rosdakarya.

Penjelasan Undang-undang No. 20 Tahun (2003) tentang Sistem Pendidikan Nasional. 
SCAFFOLDING: Jurnal Pendidikan Islam dan Multikulturalisme Vol. 01, No. 01, Januari-Juni 2019

Suparlan. (2008). Membangun Sekolah Efektif, Yogyakarta: Hikayat.

Sutikno, Sobry. (2014). Metode dan Model-model Pembelajaran. Cetakan Pertama. Lombok: Holistica.

Syafaruddin dan Irwan Nasution. (2005). Manajemen Pembelajaran, Jakarta: Bumi Aksara.

Tampubolon, Saur. (2014). Penelitian Tindakan Kelas. Jakarta : Erlangga. 